\title{
A Qualitative Inquiry of Online Instruction among Teachers in Malaysian Universities and Colleges
}

\author{
Phaik Kin Cheah, Jin Kuan Kok, and Wee Lee Chew
}

\begin{abstract}
There are many approaches in implementing online instructions in institutions of higher learning. The Malaysian government through its Malaysian Qualifications Agency, an auditing and accrediting agency, encouraged all institutions of higher learning in the country to use online instruction. The objectives of this study are to explore the views of teachers in Malaysian universities and colleges on the use of online teaching and learning. A total of 10 teachers from private institutions of higher learning in Malaysia were interviewed. Their responses were coded and the themes that emerged are presented. The results of this study present the teachers' awareness, and their views about the challenges, benefits, performance evaluations and motivation. The study also presents the teachers' views on the student attitudes and behaviors. These results are then summarized and represented in a model.
\end{abstract}

Index Terms-Web-based instruction, online environment, teacher's perspective, teacher's motivation, universities in Malaysia, student behavior.

\section{INTRODUCTION}

Online teaching instruction provides teachers a new tool and avenue to deliver information to students. As information and communication technologies advance, the applications have also expanded. Static Web 1.0 web pages have grown into interactive, responsive and open Web 2.0 applications enabling enhanced communication and social networking. These new developments pose a great challenges and greater opportunities to teachers. Past researches have attempted to explain, prove and discuss the teaching strategies and methods [1], [2], online instruction and software [3], distance learning environments [4], blended e-learning environments [5], challenges for educators and students [6] and many more. The process involves many technological gadgets, storage devices, software and hardware; and approaches including online teaching instructions and virtual classrooms [6] in order to reconstruct and adapt new technology into the traditional learning environment [7]. More recent studies discuss the pedagogy that teachers use to conduct lessons by

Manuscript submitted on February 17, 2012; revised March 6, 2012. This work was supported by the Universiti Tunku Abdul Rahman Research Fund (UTARRF).

P. K. Cheah is an Assistant Professor and Deputy Dean with the Faculty of Social Science, Universiti Tunku Abdul Rahman, Bandar Barat, 31900 Kampar, Perak, Malaysia. (e-mail: cheahpk@utar.edu.my or cheahphaikkin@gmail.com).

J. K. Kok is an Assistant Professor and Head of Programme with the Faculty of Social Science, Universiti Tunku Abdul Rahman, Bandar Barat, 31900 Kampar, Perak, Malaysia. (e-mail: kokjk@utar.edu.my).

W. L. Chew is a Senior Lecturer with the Faculty of Creative Industries, Universiti Tunku Abdul Rahman, No.3, Jalan Bersatu 13/6, 46200 Petaling Jaya, Selagor, Malaysia. (e-mail: kokjk@utar.edu.my). adapting new technologies. A researcher rightly said that "Technology should enhance the learning experience and not be the learning experience." [6]. Therefore, technology is considered as a tool for teachers and learners to enhance teaching and learning.

The constructivism learner-centered model has also been discussed in past researches where instructors play the part of facilitators to provide support and guidance [6]. This model is described as the "...obvious pedagogy for use in virtual worlds which have tools that afford the building of objects in a flexible and persistent environment." [7]. Self-directed learning has found to be a significant approach for online teaching and learning, more befitting students who are independent learners among students in institutions of higher education [4], [6]. This finding may indicate that teachers, who are also learners when it comes to new teaching and learning technologies, may also find it easier to adopt if they are self-directed learners themselves.

Despite being learner-centered, the success of online learning and the achievement of the learning outcomes were found to be dependent not only on the learner alone but also the facilitator [8]. The facilitator must play an active role in the learning process because increased interaction and timely feedback from the facilitator proved to have positive effects on the learners' exam and assignments results [8]. In a study on distance learning in Malaysia, a "hybrid mode of learning" was suggested to be more suitable for learners [4]. Past researches explained the learners' difficulties in affordability, access and time to learn new learning technologies [6], [9]. It was also found that the financial limitation in smaller institutions may be another cause for difficulties in adopting new technologies among teachers [3] as there may be limited resources to provide support such as training, upgrades, software, etc. Teachers in any case, are learners of the new teaching and learning technologies who may face the same problems as students in institutions. This indicates that further training and constant facilitation may be required by the teachers in adopting new technologies.

The Malaysian government's regulatory body for institutions of higher learning, Malaysian Qualifications Agency's (MQA) code of practice for institutional audit specifies "There must be a variety of teaching-learning methods in order to achieve the eight domains of the learning outcomes and to ensure that students take responsibility for their own learning," [10]. It also states that institutions "should establish mechanisms -- through the use of the latest technology and through global networking - to access to real time information and to identify up-to-date topics of importance for inclusion in the curriculum and its delivery." Therefore, the use of an online teaching and learning system 
would be viewed favorably as it meets the criteria for expanding teaching and learning methods, encouraging students to practice self-directed learning and providing the suggested mechanism for enhancement of content and delivery. A permissive online teaching and learning environment challenges teachers in the application and adoption technology in the "classroom". Therefore, this study focuses on the perspectives of teachers on online learning and teaching instruction. This study aims to identify the teachers' perspectives on online teaching and learning in institutions of higher learning in Malaysia using a qualitative approach.

\section{Methodology}

This is a qualitative study. Interviews were used for the data collection. It is believed to be away of learning about others [11]. Teachers from private institutions of higher learning in Malaysia were chosen on a randomly stratified base to include respondents from both genders and diverse backgrounds of disciplines and age groups. A team of 3 researchers work together for the data collecting and data analysis process. There were a total of 10 respondents comprising 4 male and 6 female teachers from five private institutions of higher learning in Malaysia. Only institutions with online instruction systems were selected as this study aims to get the perspectives of teachers who have access to an online instruction system. The respondents hold positions of tutor, lecturer, senior lecturer, assistant professor and professor and specialize in the fields of the Social Science and Humanities, Applied Sciences, Engineering and Business/Management. TABLE I shows the demographics of the participants.

TABLE I: CHARACTERISTICS OF RESPONDENTS

\begin{tabular}{cccc}
\hline \hline Respondents & Gender & Age & Position \\
\hline 1 & $\mathrm{M}$ & $50 \mathrm{~s}$ & Lecturer \\
2 & $\mathrm{M}$ & $60 \mathrm{~s}$ & Lecturer \\
3 & $\mathrm{M}$ & $40 \mathrm{~s}$ & Senior Lecturer \\
4 & $\mathrm{M}$ & $40 \mathrm{~s}$ & Lecturer \\
5 & $\mathrm{~F}$ & $30 \mathrm{~s}$ & Assistant Professor \\
6 & $\mathrm{~F}$ & $30 \mathrm{~s}$ & Senior Lecturer \\
7 & $\mathrm{~F}$ & $50 \mathrm{~s}$ & Senior Lecturer \\
8 & $\mathrm{~F}$ & $20 \mathrm{~s}$ & Tutor \\
9 & $\mathrm{~F}$ & $30 \mathrm{~s}$ & Tutor \\
10 & $\mathrm{~F}$ & $50 \mathrm{~s}$ & Lecturer \\
\hline \hline
\end{tabular}

Semi-structured questions were prepared to provide general guidelines and structure for the interview sessions. Respondents were informed of their right and were encouraged to share their experience of online teaching instruction honestly and extensively. They were also assured that materials made public would not reveal any information which could indicate their identity, location and organization. Face to face mutual dialogical approach provided an opportunity for clarification and explanation, thus the respondents' experience, their perspectives, feelings, reservations and motivations, sources of online activities, and difficulties faced were explored. Respondents were asked qualifying questions first to ensure that the institutions had an online instruction system before the interviewers explored their perspectives. Data was transcribed and coded with categories, and was analyzed by investigating the emerging issues that answer the research questions [12].

\section{FINDINGS}

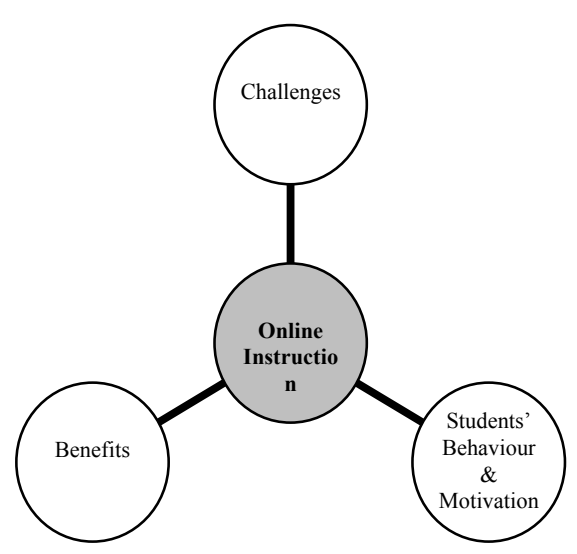

Fig. 1. Model of teachers' perception towards online instruction.

\section{A. Challenges}

\section{1) Awareness}

An unexpected finding emerged as interviewers were routinely required to ask the qualifier question on the availability of an online teaching instruction system in the organizations of the respondents. Two respondents said that it was not available in their institutions. Further investigation by the researcher revealed that the institutions in which the respondents were attached to indeed had online teaching instruction systems. Both the respondents, male lecturers in their $50 \mathrm{~s}$ and $60 \mathrm{~s}$ respectively, seem to be unaware of the availability of the systems in their institutions. Of the 8 respondents who were aware, two respondents were unaware of the exam administration function, while a total of two respondents were unaware of the online forum in the online teaching and learning system in their institutions.

\section{2) Difficulties in Adapting}

The teachers' perspectives on the challenges they faced with online instructions systems was their difficulty to adapt traditional ways of teaching to online instruction. Three respondents expressed their inability to adapt the technology into their courseware as they had previously used PowerPoint presentations and handouts. Their adoption of the online teaching and learning system involved scanning the notes and uploading the lecture/presentation slides. One respondent said "...I use the system only as storage where the students can $\log$ on to download the PowerPoint slides for my class and tutorial handouts," (Assistant Professor, Female, 30s). Another respondent described the system as "restrictive and redundant as it removes the critical part of teaching which is [through] face-to-face communication," (Male, Senior Lecturer, 40s). 


\section{3) Lack of Skills}

Six teachers expressed their lack of skills in preparing the courseware and teaching materials that could capture and sustain the interest of the students. One respondent said "All I did was to scan and upload my notes and handouts for the students to download and print. It only saves me the trouble of printing the notes and distributing it to the class which I normally do when we didn't have the system," (Female, Senior Lecturer, 30s). Another respondent said "The training that they offered us was only a one-day workshop for beginners... they tell us what the system is about and the functions we can use...but after the workshop, I just used the minimum functions to upload my notes. I can't be bothered to explore the other uses," (Female, Senior Lecturer, 50s). Meanwhile, 4 teachers suggested that on-going hands-on training and consultancy services should be made available to teachers to help them master the skill of optimizing the system.

\section{4) Time and Risks}

Another common challenge expressed by 8 respondents was the slow connection that they experienced. One respondent expressed that the slow connection may also cause him to miss a deadline. Others felt that using online teaching instruction was time-consuming as it involved constant updating, uploading and downloading of materials for their research and courseware, and responding to students' queries and discussions. One respondent said: "I find it a bit risky too as I would accidentally click on something and then my work disappears. So, I make print outs of everything. I also bring these print outs to my classes in case the system fails or the connection is slow," (Female, Senior Lecturer, 50s).

Two teachers expressed concern for the intellectual property of their courseware. If the materials were uploaded into the system it could easily be used by other institutions if the system was unsafe or if the students were to reveal their log-in information to others. "I do not trust the system for conducting tests as the students could cheat by copying each other's responses or ask another smart student to do the test for them," (Male, Lecturer, 40s).

\section{5) Lack Face-to-Face Interaction}

Five teachers remarked that using online instruction limited student-teacher interactivity and accessibility thereby limiting the teacher's ability to motivate the students, identify their weaknesses and monitor their progress. One respondent said that this was a frustrating process for him because he could not adjust the course materials to suit the needs of the students. He added: “....sometimes we get students who do not have experience in doing research as some of them did not go through the pre-university program but enrolled after STPM. They are not familiar with certain practices, so given if I expect them to learn on their own, I think they will not be able to pass the course," (Male, Lecturer, 40s).

\section{6) Performance Evaluations}

One respondent (who also holds an administrative position in his organizations) commented that both his and the department's performance appraisals were focused on the number of student enrolments and profit generated. He also said that there is no motivation for him and his fellow teachers to adopt the system although the organization had reminded them to use the system from time to time.

Meanwhile, two teachers pointed out that academic staff would not be evaluated positively in the student feedback surveys if they did not provide them with lecture slides, notes and handouts either in hard copies or softcopies (with which they could print). Therefore, it was more convenient and time-saving to upload the materials. One respondent remarked that in her performance appraisal was focused on research activities, grants and publications. She also said that student evaluations on lecturers and tutors were more focused on their teaching performance in class and availability for consultations among others.

\section{B. Benefits}

A total of 7 respondents agree that it was inevitable for private institutions to adopt online teaching and learning systems because it had to stay up-to-date. "We won't be able to create a good impression on our customers if we do not have the latest technology and services. And this industry is very competitive, so at the very least we need to have what our competitors have - not to get the competitive edge, but just to be comparable...because it is all about business and profits." (Male, Senior Lecturer - also holds an administrative position, 40s). Furthermore, one respondent expressed that it was important to have updated learning technologies to get favorable assessments from the Malaysian government's regulatory body for institutions of higher learning, Malaysian Qualifications Agency (MQA).

The benefits derived from online teaching instruction is “...that we can access it 24/7. And it saves paper." (Male, Senior Lecturer, 40s). Three teachers echoed this advantage expressing the fact that a paperless environment helped the institution to save printing and paper costs, and also the time and the stress involved in operating photocopy machines.

Furthermore, 7 respondents expressed the convenience of managing data with the online systems. It also enables "the lecturer to search for data for the development of their courseware and to conduct research," (Female, Assistant Professor, 30s).

Students benefit from an online system because they need not travel the distance and they could study at their own pace. "We have a lot of post-graduate students who are studying while they maintain a full-time job. So, it makes it easier for us to facilitate their learning from a distance. Some of them come for classes on weekends but they need to do their preparations and revisions during the week. So we have to attend to their needs," (Female, Assistant Professor, 30s).

\section{Students'Behaviors and Motivations}

The perspectives of teachers on the attitudes and behavior of students in Malaysian colleges and universities seem to be quite similar. Seven respondents expressed that students were trained/conditioned to rely on their course lecturer for information, notes and reference materials from their early education. One respondent concluded that "the Malaysian education system has been conditioning our students to be dependent on the teacher from Standard One. It is not surprising to see them behaving the same way in university," (Female, Senior Lecturer, 50s). Another respondent lamented that "We can only tell them that the notes and the assignment 
brief is online but we cannot force them to use the system." (Female, Tutor, 30s). A total of 7 teachers suggested that institutions must device a better system to motivate learners to be independent in their learning. One respondent suggested: “...one way is to award marks for participation. Students, who are IT savvy like the system but those who are not, consider it a burden," (Male, Senior Lecturer, 40s).

\section{DISCUSSION}

An unexpected finding in the interview sessions were the lack of awareness shown by the teachers. As it was not the objective of this study to test the respondents' awareness, this finding may prompt future research to examine the level of awareness, knowledge and adoption rate of the online teaching instruction. This study also found that teachers felt that having an online teaching and learning system in institutions is inevitable as it is necessary for private institutions to keep up with technological advancements to stay competitive and obtain favorable outcomes from audits done by the Malaysian regulatory body.

Besides that, teachers did not seem to be confident about their own capabilities to deliver lessons effectively through online instruction systems because of their lack of skills, hands-on training and perhaps even, motivation to use the system. Therefore, teachers, being learners themselves, need increased interactivity with trainers or facilitators to guide them develop suitable content and enhance their skills. Therefore, this finding is consistent with findings from past research which showed that learners who are self-directed make

The findings imply that teachers felt responsible for the performance and progress of their students thereby preferring to use the traditional teaching instruction whereby they could have greater accessibility and control over the learning process and achievement of learning outcomes. This finding is also consistent with past researches where increased teacher-learner interactivity has brought about better examination and assignment results [8].

It is apparent that some teachers felt vulnerable as they could not control inherent problems related to the use of online teaching and learning systems such as slow connections, users' (students) behavior and the security of their intellectual property. Therefore, it is not surprising to find most respondents feeling some resentment in adopting online teaching instruction systems as all respondents have access to the system in their institutions. Furthermore, teachers did not appear to express significant motivation to use the system as the challenges they conveyed outweigh the benefits. It appears that the respondents interpreted teaching as a process which required face-to-face communication and interaction, therefore the online teaching and learning system was considered as a supplementary tool. Despite the negative views, the respondents were aware of the benefits of using online teaching and learning system for data management and research, and also the benefits to students.

Some teachers were not motivated to use the system for the enhancement of teaching and learning because their performance evaluation by their institutions was based on student enrolments; profits generated; and research activities, grants and publications, while student evaluations were based on their teaching performance in class, availability for consultations and the materials they provide among others. Teachers remarked that most students lack motivation to use the online system. The reasons were that some students do not have access to computers and slow Internet connections and those who were not technologically savvy would not find the system useful. Students are also too dependent for handouts and input from the teacher in class.

\section{REFERENCES}

[1] K. Rollag, "Teaching Business Cases Online Through Discussion Boards: Strategies and Best Practices," Journal of Management Education, vol. 34, pp. 499, Aug. 2010.

[2] C. Tsai, "Facilitating Students to Earn Computing Certificates via Blended Learning in Online Problem-Solving Environment: A Cross-Course-Orientation Comparison," International Journal of Information and Communication Technology Education, vol. 6, pp. 11, April 2010.

[3] M. Cline, C. Guynes, and K. Simard, "Ace Project As A Project Management Tool," American Journal of Business Education, vol. 3, pp. 63-68, June 2010.

[4] W. C. Poon, K. L. T. Low, and D. G. F. Yong, "A study of Web-based learning (WBL) environment in Malaysia," International Journal of Educational Management, vol. 18, pp.374-385, Oct 2004. doi:10.1108/09513540410554031.

[5] J. H. Wu, R. D. Tennyson, and T. L. Hsia, "A study of Student Satisfaction in a Blended e-Learning System Environment," Computers \& Education, vol. 55, pp.155-164, , Aug. 2010. doi:10.1016/j.compedu.2009.12.012.

[6] S. Kala, S. Isaramalai, and A. Pohthong, "Electronic Learning and Constructivism: A Model for Nursing Education," Nurse Education Today, vol. 30, pp. 61-66, Jan. 2010. doi: 10.1016/j.nedt.2009.06.002.

[7] C. Girvan and T. Savage, "Identifying an Appropriate Pedagogy for Virtual Worlds: A Communal Constructivism Case Study," Computers and Education, vol. 55, pp. 342-349, Aug. 2010. doi:10.1016/j.compedu.2010.01.020.

[8] B. N. Potter and C. G. Johnston, "The Effect of Interactive On-line Learning Systems on Student Learning Outcomes in Accounting," International Journal of Accounting Education, vol. 24, pp.16 -34, 2006. doi:10.1016/j.jaccedu.2006.04.003.

[9] O. Wasilik and D. U. Bolliger, "Faculty Satisfaction in the Online Environment: An Institutional Study," The Internet and Higher Education, vol. 12, pp. 173-178, , Dec. 2009. doi:10.1016/j.iheduc.2009.05.001.

[10] Malaysian Qualifications Agency, Code of Practice For Institutional Audit (Second Edition). Kuala Lumpur: MQA, 2009.

[11] M. Lichtman, Qualitative Research in Education. London: Sage Publications, 2006.

[12] J. W. Creswell, Research Design ( ${ }^{\text {rd }}$ ed.). London: Sage Publications, 2009.

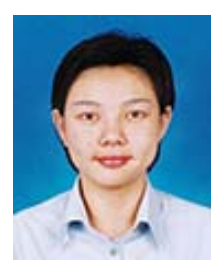

Phaik Kin Cheah was born in Penang, Malaysia. She holds a Bachelors degree in the English Language from Universiti Putra Malaysia (1998), and a Masters degree in Communication (1999) and a Doctorate degree (2005) from the Universiti Sains Malaysia. She is now an Assistant Professor and a Deputy Dean of the Faculty of Arts and Social Science, Universiti Tunku Abdul Rahman, Perak, Malaysia. She currently holds two research grants to study the ICT in education policies in Malaysia and online teaching and learning practices. Her interest is also in social work and community engagement projects. She currently collaborates with medical professionals in studying the motivations community advisory boards in a refugee camp. She was also a freelance journalist for local newspapers and magazines.

Asst. Prof. Dr Cheah is the deputy chairperson for a new village community library and a member of its community advisory board. 


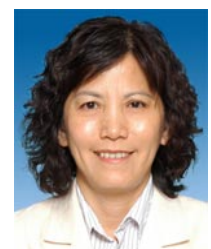

Jin Kuan Kok was born in Malaysia. BA in Chinese Literature from National Taiwan University; Master in Education (Guidance and Counselling), Durham University, England, UK; Doctorate degree in Education; Durham University, England, UK. She has extensive counselling experience working with different backgrounds of clients such as secondary school pupils with psychological and mental health challenges, parents with difficult children, family and couple counselling. She has work as a school counsellor at Raffles Girls' Secondary School (RGSS), Singapore; Senior Counsellor at Fei Yue Family Service Centre, Singapore; Senior Lecturer at TCA College, Singapore. Her present professional occupation: Assistant Professor, Department of Psychology and Counselling, Faculty of Arts and Social Science, Universiti Tunku Abdul Rahman.

Dr Kok is a registered counsellor of Singapore Association for Counsellor (SAC) and also SAC certified supervisor for counsellor. She is specialized in using a qualitative research methodology approach under constructivist and interpretative mode, to research into areas of social science.

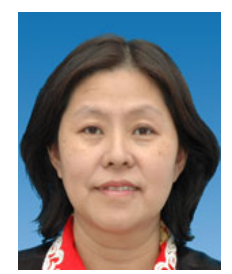

Wee Lee Chew was born in Johor Bahru, Malaysia on 27 May 1960. She obtained her Bachelor of Arts (Hons) majoring in English from the University of Malaya in 1983 and her Master of Arts in Mass Communication from University of Leicester, United Kingdom in 2005. She worked for more than a decade in the Corporate Communications field. As a manager in the Association of Banks Malaysia in 1985 to 1993 , she handled public relations projects and produced publications for the Association. She also handled media relations and events management for the Association. Among the major events she handled were ASEAN regional banking forums, luncheons for World Economic Forum delegates in Kuala Lumpur and golf tournaments for bankers in Malaysia-Singapore. She later joined Hewlett-Packard Malaysia sales office in 1993 until 1997 as the Marketing Communications Specialist, managing all aspects of Marketing Communications such as planning, managing and executing product launches, Public Relations and marketing promotions campaigns.

Wee Lee is currently a Senior Lecturer for the Bachelor of Corporate Communications programme in the Faculty of Creative Industries, Universiti Tunku Abdul Rahman (UTAR), Petaling Jaya campus, Selangor, Malaysia. Prior to joining UTAR, she taught the Murdoch University Bachelor of Public Relations programme at KDU University College, Damansara Utama, Selangor, Malaysia in 1998 to 2002. 